Annie Broadhead I Ginni Light

English for Personal Assistants 
This Book is dedicated to Ginni's son Wulfy and her mother Christa. 
Annie Broadhead I Ginni Light

\section{English for \\ Personal Assistants}

The essential handbook for doing business internationally

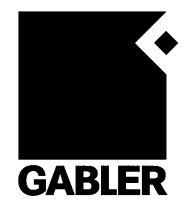


Bibliographic information published by Die Deutsche National Bibliothek

Die Deutsche National Bibliothek lists this publication in the

Deutsche Nationalbibliografie; detailed bibliographic data is available on the Internet at $<$ http://dnb.d-nb.de>.

1st edition May 2007

All rights reserved

(c) Betriebswirtschaftlicher Verlag Dr. Th. Gabler I GWV Fachverlage GmbH, Wiesbaden 2007

Editorial Office: Maria Akhavan-Hezavei

Gabler is a company of Springer Science+Business Media.

www.gabler.de

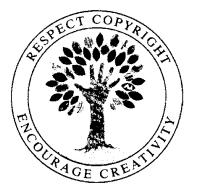

No part of this publication may be reproduced, stored in a retrieval system or transmitted, mechanical, photocopying or otherwise without prior permission of the copyright holder.

Registered and/or industrial names, trade names, trade descriptions etc. cited in this publication are part of the law for trade-mark protection and may not be used free in any form or by any means even if this is not specifically marked.

Cover design: Nina Faber de.sign, Wiesbaden

Setting: ITS Text und Satz Anne Fuchs, Bamberg

Printing and binding: Wilhelm \& Adam, Heusenstamm

Printed on acid-free paper

Printed in Germany

ISBN 978-3-8349-0130-9 


\section{Contents}

1 Communicating with clarity $\ldots \ldots \ldots \ldots \ldots \ldots \ldots \ldots \ldots \ldots \ldots \ldots \ldots \ldots \ldots \ldots \ldots, 11$

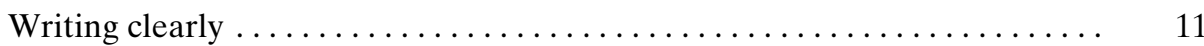

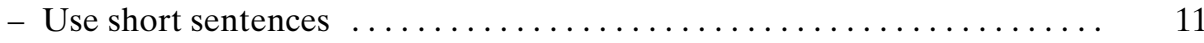

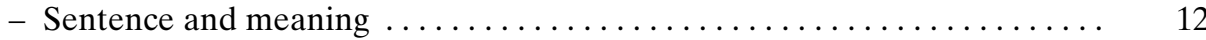

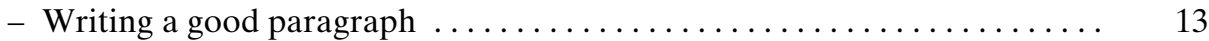

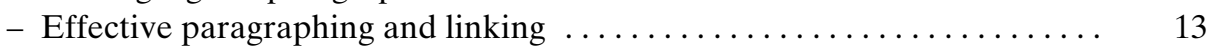

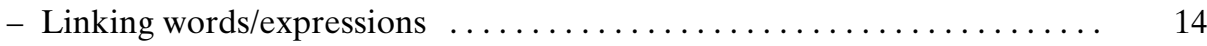

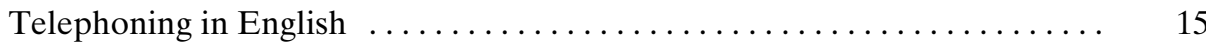

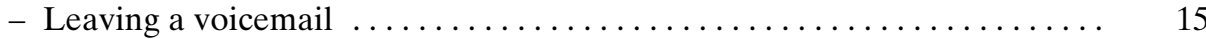

2 Best-practice emails and working in multi-cultural teams $\ldots \ldots \ldots \ldots \ldots \ldots \quad 21$

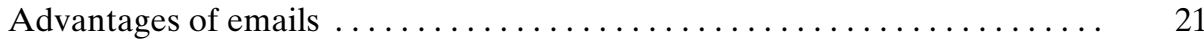

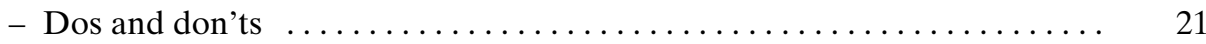

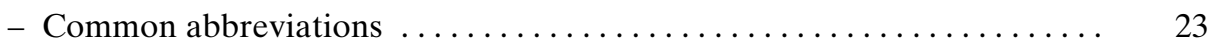

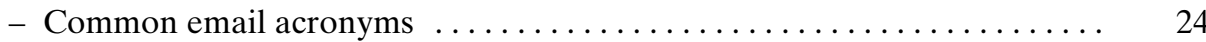

- Emoticons or Smilies .............................. 25

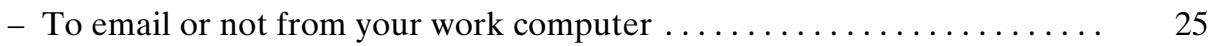

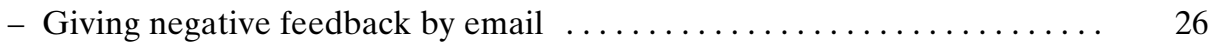

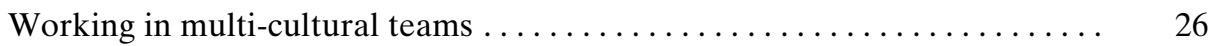

- The Challenges of Multi-Cultural Teamwork ............... 27

Raising awareness of different communication styles ........... 28

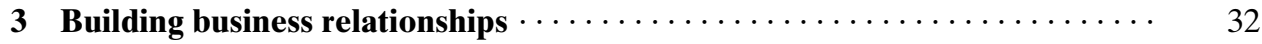

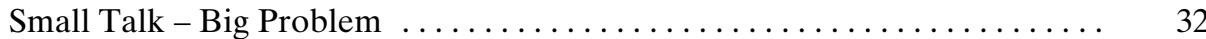

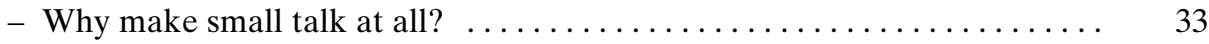

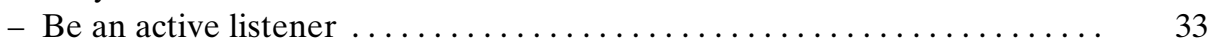

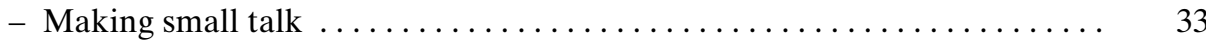

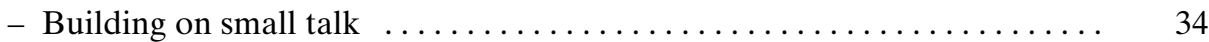

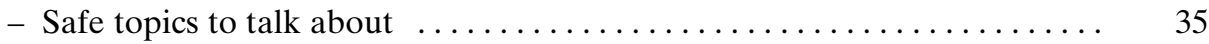

- Use open questions when you make small talk .............. 36

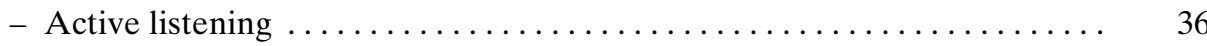

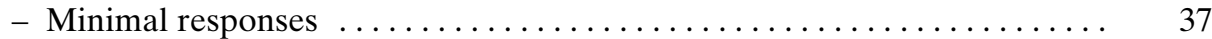

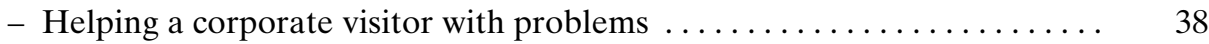

- Writing an email to a new acquaintance - formality vs informality .... 38 


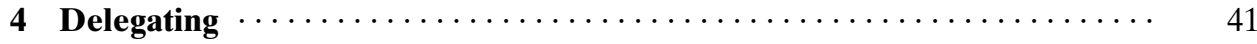

Know your team and the task requirements $\ldots \ldots \ldots \ldots \ldots \ldots \ldots \ldots . \ldots \ldots$

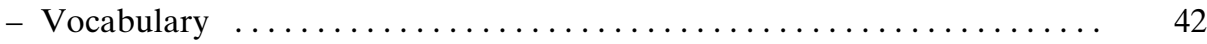

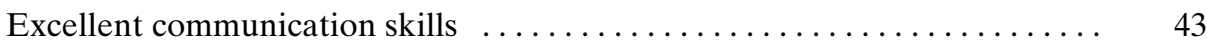

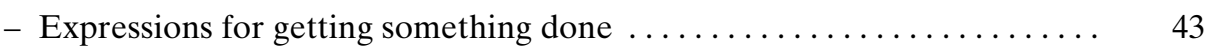

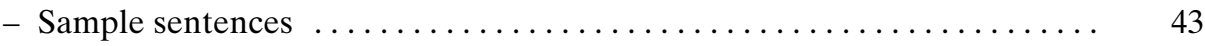

Empowering and ongoing support $\ldots \ldots \ldots \ldots \ldots \ldots \ldots \ldots \ldots \ldots \ldots \ldots \ldots \ldots \ldots \ldots \ldots$

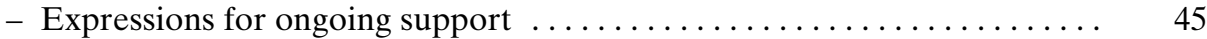

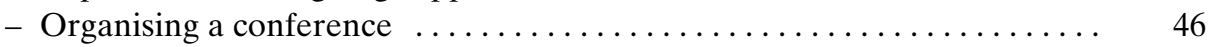

- Linking words and phrases/Describing a process $\ldots \ldots \ldots \ldots \ldots \ldots . \ldots \ldots$

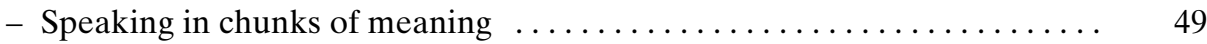

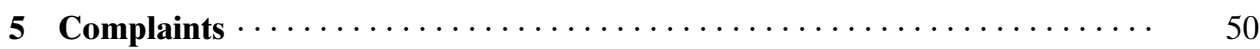

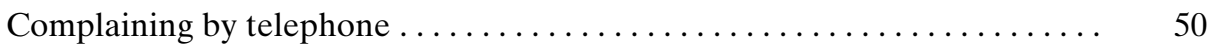

- Key factors in complaining whilst maintaining the relationship ...... 52

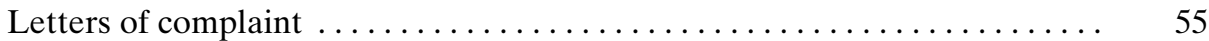

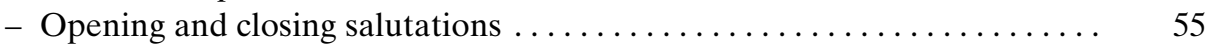

- Linking words and phrases for comparing and contrasting ......... 57

6 Proposals and reports $\ldots \ldots \ldots \ldots \ldots \ldots \ldots \ldots \ldots \ldots \ldots \ldots \ldots \ldots \ldots \ldots \ldots \ldots$

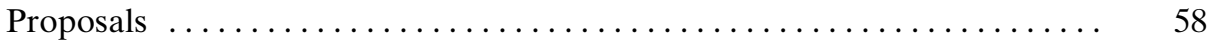

- First and Foremost/The concept ...................... 58

- Know the target reader $\ldots \ldots \ldots \ldots \ldots \ldots \ldots \ldots \ldots \ldots \ldots \ldots \ldots \ldots \ldots$

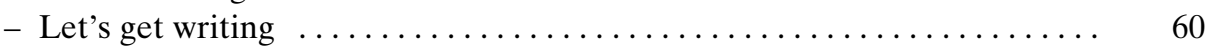

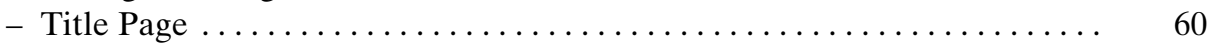

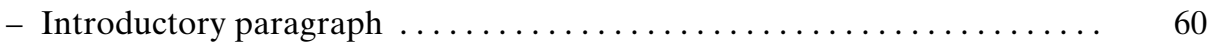

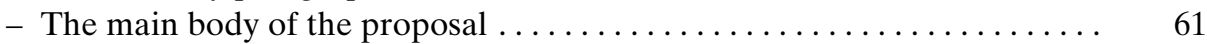

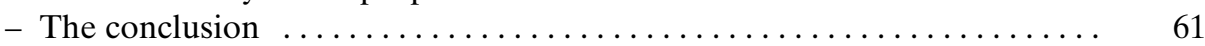

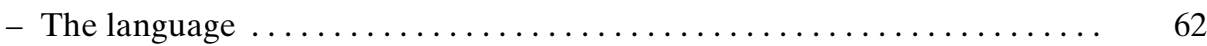

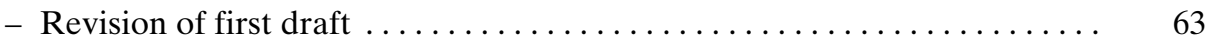

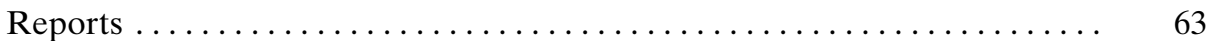

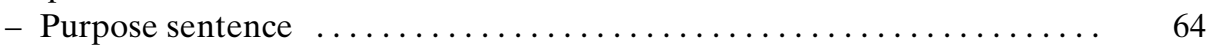

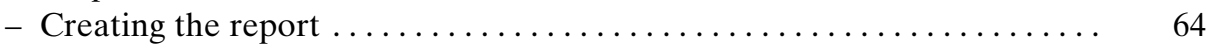

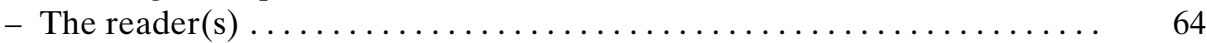

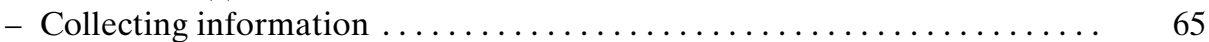

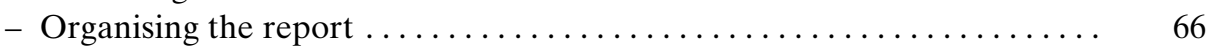

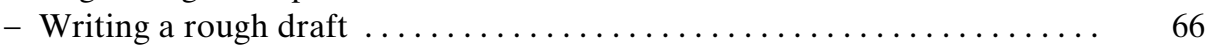

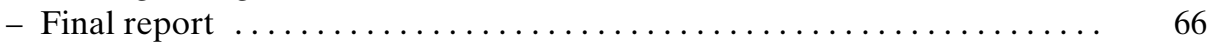




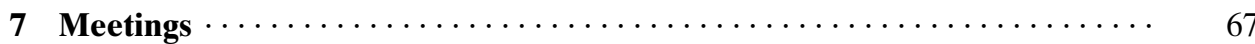

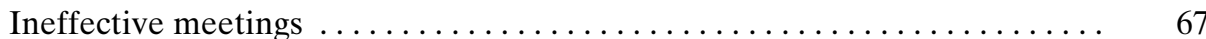

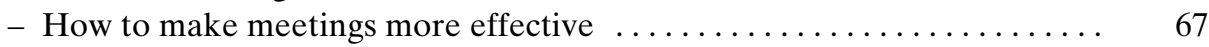

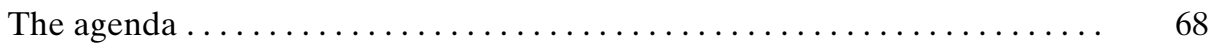

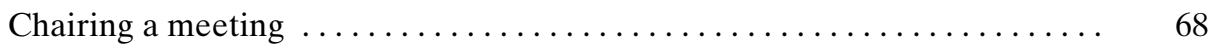

Participating in a meeting $\ldots \ldots \ldots \ldots \ldots \ldots \ldots \ldots \ldots \ldots \ldots \ldots \ldots \ldots \ldots$

- Expressions for agreeing/disagreeing and giving opinions . . . . . . 71

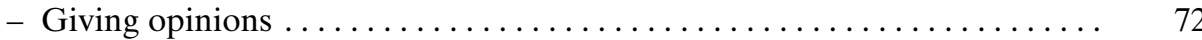

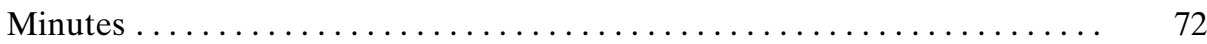

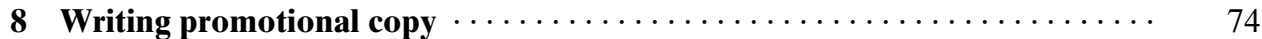

What's the purpose of the text you're writing? .............. 74

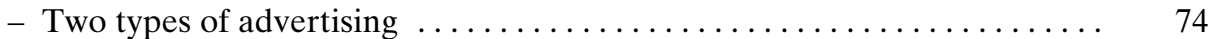

- Getting the reader's attention: Headlines . . . . . . . . . . . . . 75

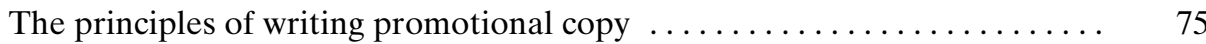

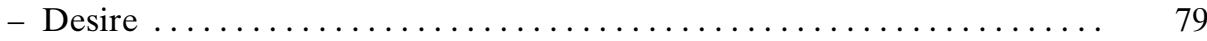

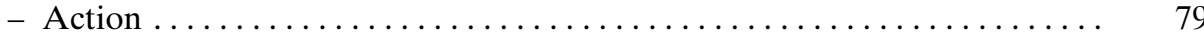

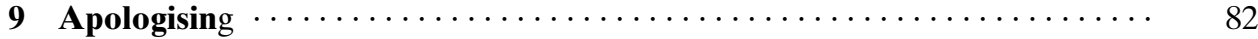

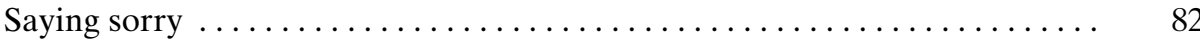

Accepting apologies $\ldots \ldots \ldots \ldots \ldots \ldots \ldots \ldots \ldots \ldots \ldots \ldots \ldots \ldots \ldots \ldots \ldots \ldots$

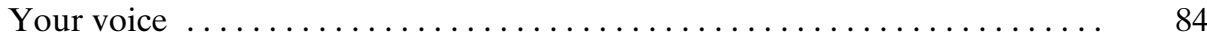

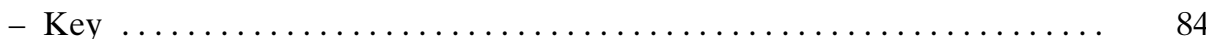

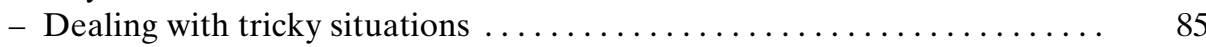

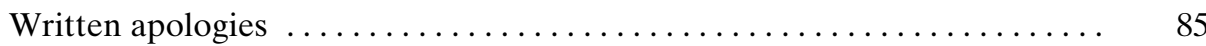

The language of apologies $\ldots \ldots \ldots \ldots \ldots \ldots \ldots \ldots \ldots \ldots \ldots \ldots \ldots$

10 Giving presentations with impact $\ldots \ldots \ldots \ldots \ldots \ldots \ldots \ldots \ldots \ldots \ldots \ldots \ldots$

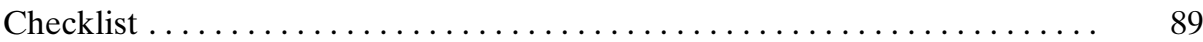

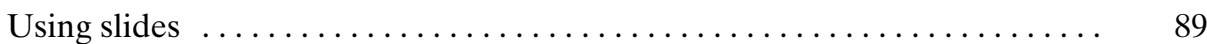

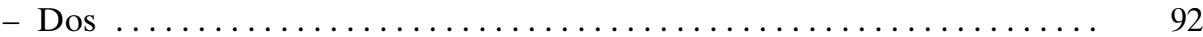

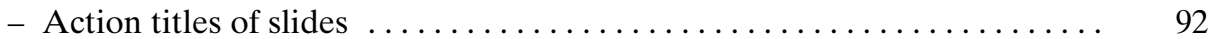

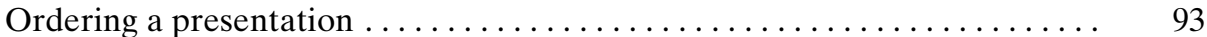

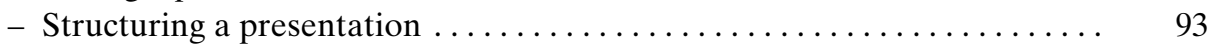

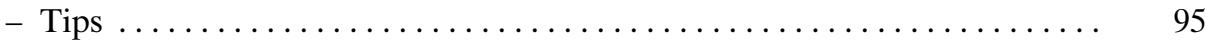

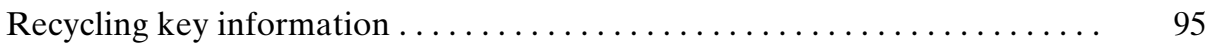

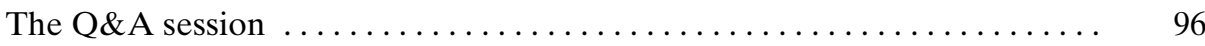




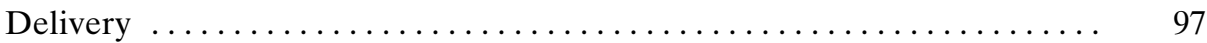

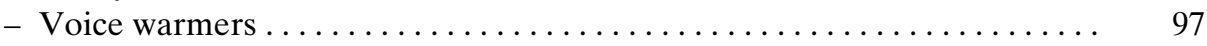

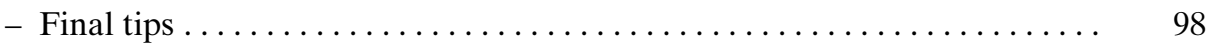

11 Team building and giving/receiving feedback $\ldots \ldots \ldots \ldots \ldots \ldots \ldots \ldots$

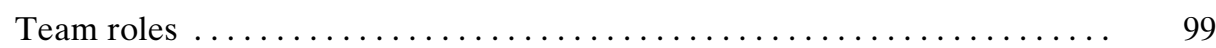

Dealing with different team players $\ldots \ldots \ldots \ldots \ldots \ldots \ldots \ldots \ldots \ldots \ldots \ldots$

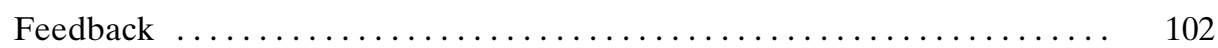

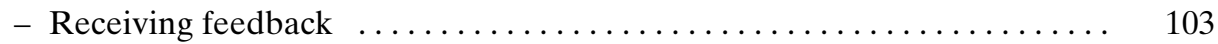

- Giving feedback .................................... 104

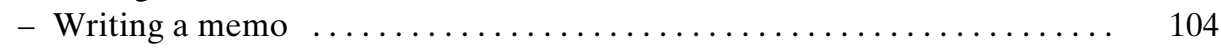

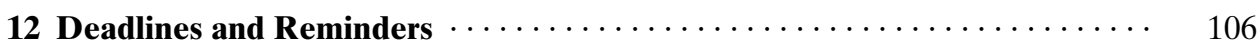

Asking to have deadlines extended or workload reduced $\ldots \ldots \ldots \ldots \ldots . . \ldots 6$

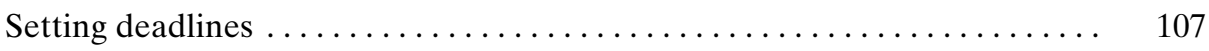

Getting people to stick to deadlines . . . . . . . . . . . . . 107

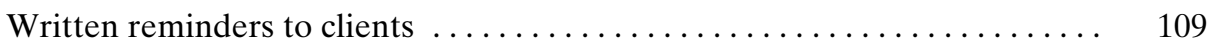

- The language of deadlines and reminders $\ldots \ldots \ldots \ldots \ldots \ldots \ldots \ldots \ldots . \ldots \ldots$

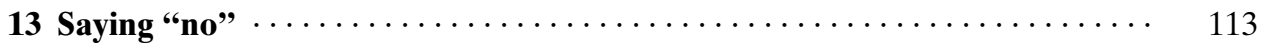

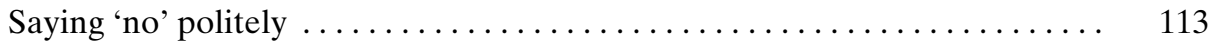

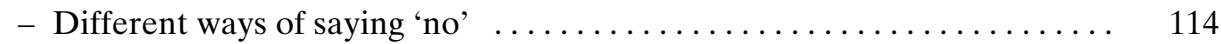

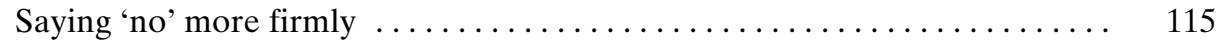

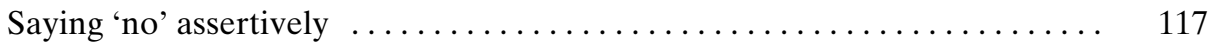

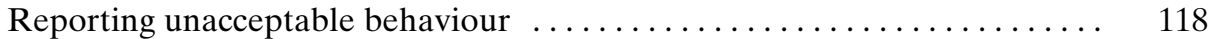

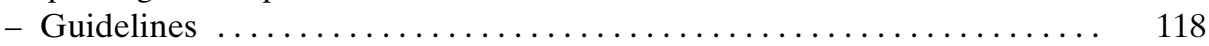

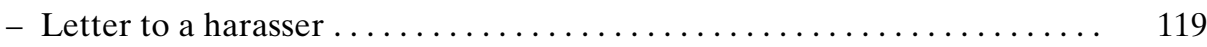

- Harassment report to manager ....................... 120

14 Writing CVs with impact, covering letters, and letters of reference $\ldots \ldots \ldots \quad 122$

How do you prepare to write a CV? . . . . . . . . . . . . . 122

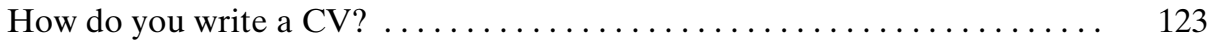

- Dos and don'ts when you write a CV ................... 125

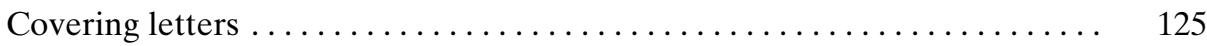

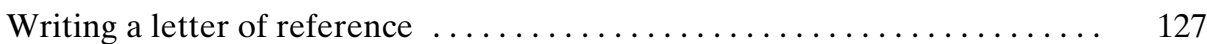

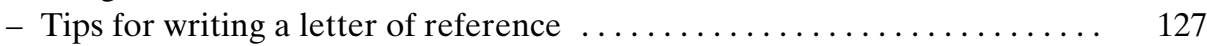

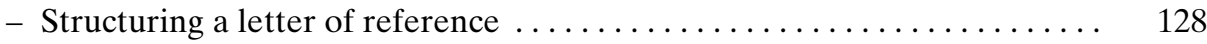


15 Conference invitations and requests for abstracts, cards for various occasions $\ldots \ldots \ldots \ldots \ldots \ldots \ldots \ldots \ldots \ldots \ldots \ldots \ldots \ldots \ldots \ldots \ldots$

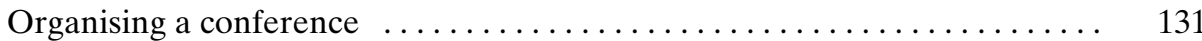

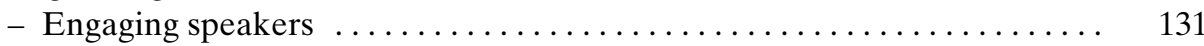

- Call for papers and abstracts . . . . . . . . . . . . . . . . . 132

- Letter of invitation to a conference speaker ................. 133

Writing cards - useful phrases for various occasions . . . . . . . . . . . 134

- Get-well cards .................................... 134

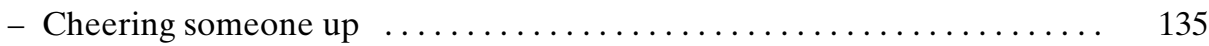

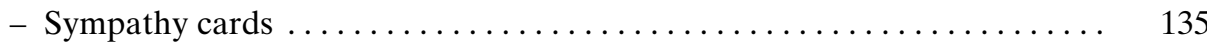

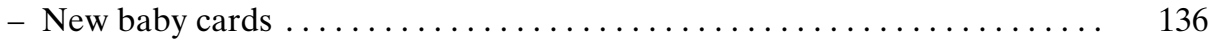

- Congratulations ................................... 136

- Work anniversaries ................................ 137

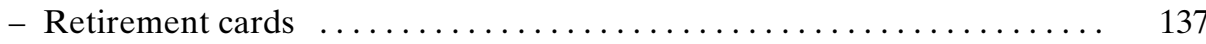

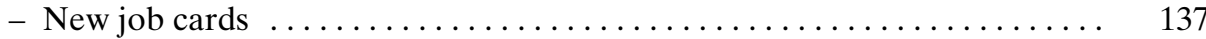

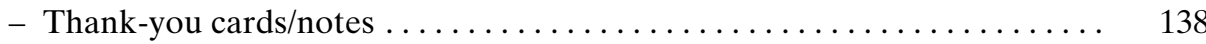

16 Influencing strategies and tactics $\ldots \ldots \ldots \ldots \ldots \ldots \ldots \ldots \ldots \ldots \ldots \ldots \ldots \ldots \ldots \ldots \ldots$

How to influence people and win friends $\ldots \ldots \ldots \ldots \ldots \ldots \ldots \ldots . \ldots \ldots$

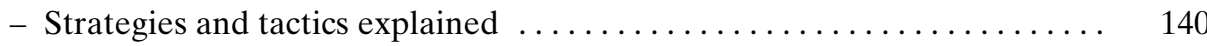

- Negative tactics - beware how you use them! . . . . . . . . . . . . . . . . . 141

- Good influencers are fun to be around ...................... ${ }^{14} 141$

The Myers Briggs Type Indicator (MBTI) . . . . . . . . . . . . . . . 142

- Working out your Myers Briggs type $\ldots \ldots \ldots \ldots \ldots \ldots \ldots \ldots \ldots \ldots . \ldots \ldots$

17 Dealing with difficult people $\ldots \ldots \ldots \ldots \ldots \ldots \ldots \ldots \ldots \ldots \ldots \ldots \ldots \ldots \ldots \ldots \ldots$

Dealing with different types of difficult people $\ldots \ldots \ldots \ldots \ldots \ldots \ldots \ldots$.

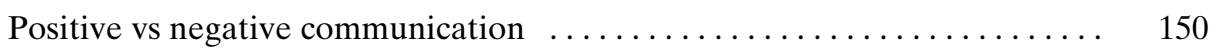

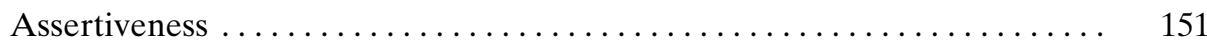

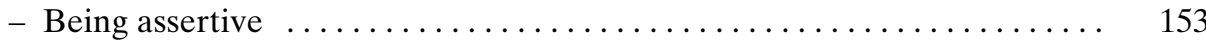

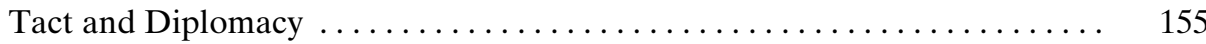

- Making language more diplomatic ..................... 155

Appendix A Linking Words - A Summary $\ldots \ldots \ldots \ldots \ldots \ldots \ldots \ldots \ldots \ldots \ldots \ldots \ldots$

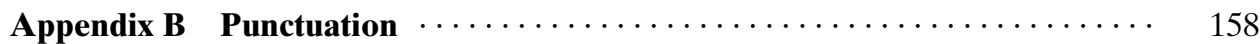

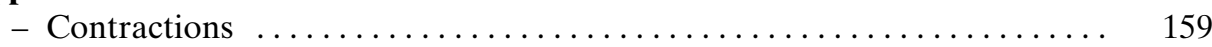

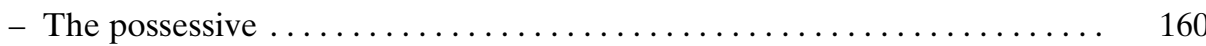

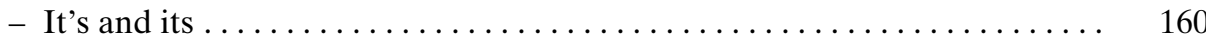


Appendix C Proofreader's marks $\ldots \ldots \ldots \ldots \ldots \ldots \ldots \ldots \ldots \ldots \ldots \ldots \ldots \ldots \ldots \ldots \ldots$

Appendix D The use of the articles a/an/the/ zero (no) article $\ldots \ldots \ldots \ldots \ldots$

Appendix E Conditional forms in the English language $\ldots \ldots \ldots \ldots \ldots \ldots \ldots$

1 Communicating with clarity KEY $\ldots \ldots \ldots \ldots \ldots \ldots \ldots \ldots \ldots \ldots \ldots \ldots \ldots \ldots \ldots \ldots \ldots \ldots$

2 Best-practice emails and working in multi-cultural teams KEY $\ldots \ldots \ldots \ldots$

3 Building business relationships KEY $\ldots \ldots \ldots \ldots \ldots \ldots \ldots \ldots \ldots \ldots \ldots \ldots \ldots$

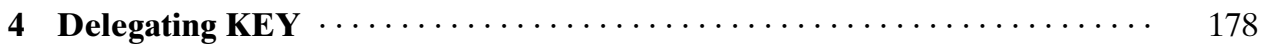

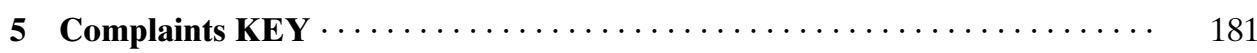

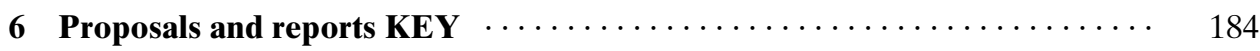

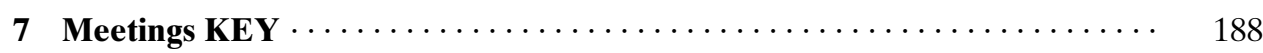

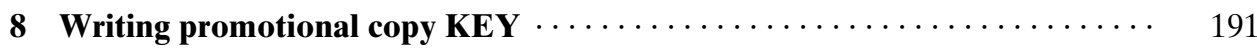

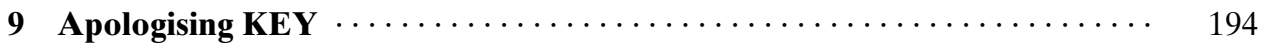

10 Giving presentations with impact KEY $\ldots \ldots \ldots \ldots \ldots \ldots \ldots \ldots \ldots \ldots \ldots \ldots \ldots$

11 Team building and giving/receiving feedback KEY $\ldots \ldots \ldots \ldots \ldots \ldots \ldots$

12 Deadlines and reminders KEY $\ldots \ldots \ldots \ldots \ldots \ldots \ldots \ldots \ldots \ldots \ldots \ldots \ldots \ldots \ldots \ldots \ldots \ldots \ldots$

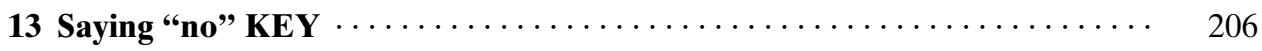

14 Writing CVs with impact, covering letters, and letters of reference KEY ‥ 209

15 Conference invitations and requests for abstracts, cards for various occasions KEY $\ldots \ldots \ldots \ldots \ldots \ldots \ldots \ldots \ldots \ldots \ldots, 211$

16 Influencing strategies and tactics KEY $\ldots \ldots \ldots \ldots \ldots \ldots \ldots \ldots \ldots \ldots \ldots \ldots \ldots \ldots \ldots$

17 Dealing with difficult people KEY $\ldots \ldots \ldots \ldots \ldots \ldots \ldots \ldots \ldots \ldots \ldots \ldots \ldots \ldots \ldots$ 